\begin{tabular}{|c|c|c|}
\hline$\overline{\bar{J}}$ & $\begin{array}{l}\text { International Journal of Current Research in } \\
\text { Biosciences and Plant Biology }\end{array}$ & \\
\hline & Volume $4 \bullet$ Number 6 (June-2017) • ISSN: 2349-8080 (Online) & \\
\hline $\begin{array}{l}\text { EXCELLENI } \\
\text { PUBLISHERS }\end{array}$ & Journal homepage: www.ijcrbp.com & www.ijothp com \\
\hline
\end{tabular}

Review Article

doi: https://doi.org/10.20546/ijcrbp.2017.406.011

\title{
Evaluation of Jatropha curcas as Potential Biocide and Biopesticide
}

\author{
Neha Sharma* \\ University of Delhi, Delhi-110 007, India \\ *Corresponding author.
}

\begin{tabular}{ll}
\hline Abstract & Article Info \\
Jatropha curcas (Linnaeus) belongs to the family of Euphorbiaceae and has been widely & Accepted: 28 May 2017 \\
known as biofuel crop. Apart from being considered as biofuel crop, Jatropha is also & Av June 2017 \\
known to possess insecticidal/antifeedant activity. This biopesticide property of Jatropha & \\
$\begin{array}{l}\text { can be attributed to its specific chemical constituents that can target pest during different } \\
\text { stages of life cycle. Chemical constituents such as phorbol esters and terpenoid }\end{array}$ & Keywords \\
$\begin{array}{l}\text { compounds are responsible for high bioactivity of Jatropha. This paper attempts to } \\
\text { evaluate potential of Jatropha as biocide and biopesticide. This study highlights }\end{array}$ & $\begin{array}{l}\text { Antifeedant } \\
\text { impopesticide }\end{array}$ \\
management program. & $\begin{array}{l}\text { Insecticidal activity } \\
\text { Jatropha curcas }\end{array}$
\end{tabular}

\section{Introduction}

Jatropha curcas (Linnaeus) belongs to the family of Euphorbiaceae and has been widely known as biofuel crop (Openshaw, 2000). Jatropha is originally native of tropical America, but now is widely common in many parts of the tropics and sub-tropics in Africa/Asia. Another important advantage with this crop is that it is easy to establish, grows relatively quickly and is hardy and also drought tolerant. It can grow well even in marginal/poor soil. It is easy to establish, grows relatively quickly and lives, producing seeds for 50 years. Oil content in seeds of Jatropha is $37 \%$. The oil derived from seeds can be used as fuel without being refined. This oil has potential to undergo combustion with clear smoke-free flame. It has been tested successfully as fuel for simple diesel engine. Jatropha curcas is becoming the future source of biodiesel for India. It is found to be growing in many parts of the country, and can grow with minimum inputs (Mittelbach, 1983). Among the various oil seeds, Jatropha curcas has been found more suitable for biodiesel production. It is possible to grow this plant under stress condition and the oil of these species have various characteristics which makes it suitable for biodiesel production. Jatropha oil has higher cetane no. (51) as compared to other oils which make it an ideal alternative fuel for engine (Jain and Sharma, 2010).

There are many advantages associated with Jatropha. One advantage of Jatropha is that it can be grown in arid zones (20 cm rainfall) as well as in higher rainfall zones. This plant is a quick yielding species even in adverse land situations, such as degraded and barren lands under forest and non-forest use, dry and drought prone area and marginal lands with alkaline soils. It is also considered as good plant material for ecorestoration in all types of wasteland. Jatropha is not 
considered to be good forage material. Moreover this plant is highly pest and disease resistant. Jatropha is also important from ecological point of view as it removes carbon from the atmosphere, stores it in the woody tissues and assists in the build-up of soil carbon. The plant also holds application to prevent and/or control erosion, to reclaim land, to act as a live fence, especially to contain or exclude farm animals and to be planted as a commercial crop. It is not browsed by animals as its leaves and stems are distasteful to animals. However, after treatment, the seeds or seed cake could be used as an animal feed. All parts of the plant are of medicinal value. Bark of Jatropha contains tannin which attracts bees and thus the plant has a honey production potential. Wood and fruit of this plant can be used for numerous purposes including fuel production. Its fruit contain viscous oil that can be used for soap making, in the cosmetics industry and as a diesel/kerosene substitute or extender. Its use as biodiesel is important because it can be considered as practical substitutes for fossil fuels to counter greenhouse gas accumulation. However, the full potential of Jatropha has not been fully realized due to several reasons. Firstly, the growing and management of Jatropha is poorly documented. Secondly, there are fewer efforts put forward towards marketing its products. Therefore, actual or potential growers are generally reluctant to invest time and money in a crop that only has promise rather than concrete rewards.

Primarily, Jatropha has been well studied for its properties to serve as biodiesel in future (Kumar and Sharma, 2008). It is well known that Jatropha oil can be used as fuel in diesel engines directly and by blending it with methanol (Gubitz et al., 1999). Experimental testing of engines with Jatropha oil in Thailand has revealed satisfactory engine performance (Takeda, 1982). A technique to produce biodiesel with high free fatty acids contents (15\% FFA) from Jatropha has been developed by Berchmans and Hirata (2008) and Tiwari et al. (2007). This technique involved two-stage transesterification process to improve methyl ester yield. The first stage involved the acid pretreatment process to reduce the FFA level of crude Jatropha seed oil to less than $1 \%$ and second was the alkali base catalyzed transesterification process which gave 90\% methyl ester yield. Efforts have also been put forward by researchers to reduce cost of biofuel production from Jatropha. In this regard, the lipase producing whole cells of Rhizopus oryzae immobilized onto biomass support particles was used and found to be a promising biocatalyst for producing biodiesel (Tamalampudi et al., 2007). Higher oil extraction can result in more profit since oil sells for more than the residual seed cake. In order to increase such profits, efforts have also been done by researchers to innovate new techniques to increase oil percentage. Higher $\%$ of oil from the Jatropha seeds can be extracted using more efficient expeller system. The simple technology specially developed for this chemical process can also be performed in less industrialized countries (Mittelbach et al., 1983; Connemann, 1994). Application of methyl ester of Jatropha oil and dual fuel operation with methanol induction can give better performance and reduced smoke emissions than the blend. Sarin et al. (2007) have examined the blends of Jatropha and Palm biodiesel for their physico-chemical properties to get optimum mix of them to enhance oxidation stability needed for South Asian and South East-Asian countries.

Apart from potential of Jatropha as biofuel, Jatropha has insecticidal/antifeedant activity therefore making it ideal potential option for incorporation into pest management program.

\section{Jatropha as biocide and biopesticide}

A substance that kills or retards the growth of microorganisms and is considered to cause minimal or no harm to the environment is a green, or eco-friendly, biocide (Ashraf et al., 2013). According to the European Commission's Biocidal Product Directive 98/8/EC (2013), biocides can be divided into four main typesdisinfectant, preservative, pest control and other biocidal products - and further classified into 23 product types, including approximately 955 substances and 372 notified substances. Biocide which is effective against microorganisms, economical and compatible with the environment, is preferred for industrial requirement. There is need to explore broad-spectrum green microbiocides with very low toxicity, environmental acceptability, and that are safe and easy to handle and store (Ashraf et al., 2013). The green biocide is determined according to the principles of green chemistry; a biocide must fulfill all of the requirements before it can be declared safe for living beings and the environment and be considered green (Ashraf et al., 2013). Biocidal potential of Jatropha curcas is an emerging new aspect of the plant. The main biocidal action among Jatropha curcas extracts, has been ascribed to the phorbol ester (tetracyclic deterpenoid) fraction from the seed oil (Ratnasdass and Wink, 2012). 
Phorbol ester present in this plant is a member of the tigliane family of diterpenes (Makkar et al., 2007). Phorbol ester in Jatropha show biocidal as well as insecticidal activity due to the stimulation of the cellular target protein Kinace $\mathrm{C}$ (PKC). This fraction has also application as a plant-derived protectant of a variety of crops, from a range of pre-harvest and post-harvest insect pests (Ratnasdass and Wink, 2012). Jatropha extract inhibit growth of various bacteria as summarized in Table 1.

Table 1. Effect of Jatropha extract on growth of bacteria.

\begin{tabular}{|c|c|c|}
\hline Bacteria & Result & Reference \\
\hline Citrobacter freundii & Decrease & Dada et al. (2014) \\
\hline \multirow[t]{2}{*}{ Enterobacter aerogenes } & Decrease & Setha et al. (2014) \\
\hline & & Dada et al. (2014) \\
\hline Enterococcus faecalis & Decrease & Suhaili et al. (2011) \\
\hline Escherichia coli & Decrease & $\begin{array}{l}\text { Rampadarath et al. (2016); Abubakar et al. (2016); Kuta et al. (2015); } \\
\text { Dada et al. (2014); Suhaili et al. (2011); Kalimuthu et al. (2010) }\end{array}$ \\
\hline Klebsiella pneumonia & Decrease & Abubakar et al. (2016); Dada et al. (2014); Suhaili et al. (2011) \\
\hline Listeria monocytogenes & Decrease & Suhaili et al. (2011) \\
\hline Morganella morgenii & Decrease & Suhaili et al. (2011) \\
\hline Pseudomonas aeruginosa & Decrease & Abubakar et al. (2016); Kuta et al. (2015) \\
\hline Salmonella enterica & Decrease & Suhaili et al. (2011) \\
\hline Salmonella typhi & Decrease & Abubakar et al. (2016); Kuta et al. (2015) \\
\hline Serratia marcescens & Decrease & Suhaili et al. (2011) \\
\hline Serratia marcescens & Decrease & Dada et al. (2014) \\
\hline Staphylococcus aureus & Decrease & Abubakar et al. (2016); Kuta et al. (2015); Suhaili et al. (2011) \\
\hline Streptococcus agalactiae & Decrease & Suhaili et al. (2011) \\
\hline Shigella dysenteriae & Decrease & Igbinosa et al. (2009) \\
\hline
\end{tabular}

Jatropha curcas has significant properties to be considered as biopesticide. Its seed oil has also been used to reduce infestation of insect pests [Aphids crassivora Koch (Hemiptera: Aphididae), Marucates tulalis F. (Lepidoptera: Crambidae) and Megalurothrips sjostedti Trybom (Thysanoptera: Thripidae)] in cowpea (Ahuchaogu et al., 2014). In another study the acetonolic, ethanolic and water extracts of the root and seeds of Jatropha curcas exhibited satisfactory insecticidal bioactivity which can successfully substitute chlorpyrifos (synthetic insecticide) in the control of insect Oecophylla longinoda (Ojiako et al., 2015).

Insecticidal activities of Jatropha curcas plant parts have also been reported against mosquitoes, Anopheles arabiensis Patton (Diptera: Culicidae) (Zewdneh et al., 2011), Sitophilus zeamais Motschulsky (Coleoptera: Curculionidae) (Ojiako et al., 2014), mites, Rhipicephalus (Boophilus) annulatus (Ixodida: Ixodidae) (Juliet et al., 2012), cockroaches, Periplaneta americana Linnaeus (Blattodea: Blattidae) (Lateef et al., 2014), Desert locusts, Schistocerca gregaria Forskal (Orthoptera: Acrididae) (Bashir and Shafie, 2013), Busseola fusca Fuller (Lepidoptera: Noctuidae) and Sesamia calamistis Hampson (Lepidoptera: Noctuidae) (Makkar et al., 2007), Helicoverpa zea Boddie (Lepidoptera: Noctuidae) (Olapeju et al., 2008), termites; Coptotermes (Blattodea: Rhinotermitidae) and Odontotermes obesus Rambur (Blattodea: Termitidae) (Acda, 2009a, 2009b; Verma et al., 2011). Table 2 summarizes effect of Jatropha extract on growth of different insects.

Biopesticide property of seed oil of Jatropha can be attributed to its specific chemical constituent which can target pest during different stages of life cycle. Seed oil derived from Jatropha have been reported to effect oviposition deterrence and inhibited egg hatching in potato tuber moth, Phthorimaea operculella Zeller (Lepidoptera: Gelechiidae) (Shelke et al., 1987). It also inhibited growth of tobacco hornworm, Manduca sexta Linnaeus (Lepidoptera: Sphingidae) larvae (Sauerwein et al., 1993). Application of Jatropha seed oil had resulted in anti-ovipositional activity and longterm protective ability of treated cowpeas against the seed beetle Callosobruchus maculatus F. (Coleoptera: Chrysomelidae: Bruchinae) (Adebowale and Adedire, 2006). Moreover its application has reduced the number of tested insect pests (Aphids crassivora, Maruca testulalis and Megalurothrips sjostedti) in a field trial to control field pests of cowpea (Ahuchaogu et al., 2014). Recently, Jatropha curcas has been reported to increase mortality of black moth (Ingle et al., 2017). 
Table 2. Effect of Jatropha extract on growth and number of different insects.

\begin{tabular}{lll}
\hline Insect & Result & Reference \\
\hline Black moth & Decrease & Ingle et al. (2017) \\
Helicoverpa armigera & Decrease & Ingle et al. (2017) \\
Bactrocera cucurbitae & Decrease & Rampadarath et al. (2016) \\
Oecophylla longinoda & Decrease & Ojiako et al. (2015) \\
Callosobruchus maculatus & Decrease & Ahuchaogu and Ojiako (2015) \\
Sitophilus zeamais & Decrease & Ojiako et al. (2014) \\
Aphids crassivora & Decrease & Ahuchaogu et al. (2014) \\
Maruca testulalis & Decrease & Ahuchaogu et al. (2014) \\
Megalurothrips sjostedti & Decrease & Ahuchaogu et al. (2014) \\
Periplanata americana & Decrease & Lateef et al. (2014) \\
Schistocerca gregaria & Decrease & Bashir and Shafie (2013) \\
Rhipicephalus annulatus & Decrease & Juliet et al. (2012) \\
Anopheles arabiensis & Decrease & Zewdneh et al. (2011) \\
Odontotermes obesus & Decrease & Verma et al. (2011) \\
Coptotermes vastator & Decrease & Acda (2009a); Acda (2009b) \\
Helicoverpa zea & Decrease & Olapeju et al. (2008) \\
Culex quinquefasciatus & Decrease & Kovendan et al. (2011) \\
\hline
\end{tabular}

This high bioactivity of Jatropha oil can be attributed to the presence of phorbol esters in the kernels, stem, flowers, buds, roots, bark (outer brown and inner green) skins and wood (Makkar et al., 1998). Jatropha species also contain terpenoid compounds, among which are diterpenoid compounds with about 68 diterpenes (Devappa et al., 2010a).

Majority of these diterpenes are cytotoxic, antitumor and antimicrobial activities while the phorbol ester, lignans, cyclic peptides, terpenes and Jatropherol display insect deterrent and a broad range of biological activities (Devappa et al., 2010b). Further phytochemical analysis of the root, stem and petiole of the plant showed the presence of alkaloids, saponins, tannins, terpenoids, steroids, glycosides, phenols and flavonoids (Sharma et al., 2012) which are known to have bactericidal, fungicidal and antimicrobial properties (Rachana et al., 2012; Narayani et al., 2012; Egharevba and Kunle, 2013). The seed is known to possess a generous amount of curcintoxalbumin (Stirpe et al., 1976) which is known to inhibit protein synthesis in-vitro. The modification of amino acids (arginine, lysine, and tryptophan) in the active site results in loss of the inhibitor activity (Weike et al., 2006) which may be fatal to insects.

\section{Conclusion}

The present paper indicates that Jatropha has an immense potential for biocide and biopesticide. Since this crop is drought tolerant and can survive harsh climatic conditions, therefore it can play an important for developing green biocide in future. This plant has biocide as well as biopesticide property which can be utilized further by including it into pest management program.

\section{Conflict of interest statement}

Author declares that there is no conflict of interest.

\section{References}

Abubakar, S., Akanbi, B.O., Osuji, C., Phillip, E.A., 2016. Evaluation of pharmacological potentials of Jatropha curcas Linn sap Euphorbiaceae family. Pharmaceut. Biol. Evaluat. 3(3), 334-342.

Acda, M.N., 2009a. Toxicity, tunnelling and feeding behavior of the termite, Coptotermes vastator Light (Isoptera: Rhinotermitidae) in sand treated with oil of the physic nut, Jatropha curcas. J. Insect Sci. 9, 1-8.

Acda, M.N., 2009b. Evaluation of oil of the physic nut, Jatropha curcas L. (Malpighiales: Euphorbiceae) against the Philippine milk termite, Coptotermes vastator Light (Isoptera: Rhinotermitidae). J. Insect Sci. 9, 1-8.

Adebowale, K.O., Adedire, C.O., 2006. Chemical composition and insecticidal properties of the underutilized Jatropha curcas seed oil. Afr. J. Biotechnol. 5(10), 901-906.

Ahuchaogu, C.E., Ojiako, F.O., 2015. Comparative study of the toxic effects of Jatropha curcas L. extracts and actellic 25 e.c ${ }^{\circledR}$ on Callosobruchus maculatus (Fabricius) (Coleoptera: Chrysomelidae: Bruchinae) in stored cowpea. FUTA J. Res. Sci. 2, 231-242. 
Ahuchaogu, C.E., Ojiako, F.O., Kabeh, J.D., 2014. Evaluation of Jatropha curcas Lam. extracts in the control of some field insect pests of cowpea (Vigna unguiculata L. Walp). Int. J. Scient. Technol. Res. 3(3), 136-141.

Ashraf, M.A., Ullah, S., Ahmad, I., Qureshi, K., Balkhair, K.S., Rehman, M.A., 2013. Green biocides, a promising technology: current and future applications to industry and industrial processes. J. Sci. Food Agric. 94, 388-483.

Bashir E. M., Shafie, H.A.F., 2013. Insecticidal and antifeedant efficacy of Jatropha oil extract against the desert locust, Schistocerca gregaria (Forskal) (Orthoptera: Acrididae). Agric. Biol. J. North Amer. 4(3), 260-267.

Berchmans, H.J., Hirata, S., 2008. Biodiesel production from crude Jatropha curcas L. seed oil with a high content of free fatty acids. Bioresour. Technol. 99, 1716-1721.

Connemann, J., 1994. Biodiesel in Europa 1994. Eur. J. Lipid Sci. Technol. 96(S2), 536-548.

Dada, E.O., Ekundayo, F.O., Makanjuola, O.O., 2014. Antibacterial activities of Jatropha curcas (Linn) on coliforms isolated from surface waters in Akure, Nigeria. Int. J. Biomed. Sci. 10(1), 25-30.

Devappa, R.K, Makkar, H.P.S., Becker, K., 2010 b. Jatropha toxicity: A review. J. Toxicol. Environ. Health. 13, 476-507.

Devappa, R.K., Makkar, H.P.S., Becker, K., 2010a. Jatropha diterpenes: A review. J. Amer. Oil Chemists' Soc. 88(13), 301-322.

Directive 98/8/EC of the European Parliament and of the Council concerning the placing of biocidal products on the market (2013). [http://ec.europa.eu/ environment/biocides].

Egharevba, H.O., Kunle, O.F., 2013. Broad spectrum antimicrobial activity of extracts of Jatropha curcas. J. Appl. Pharmacol. Sci. 3(04), 083-087.

Gubitz, G.M., Mittelbech, M., Trabi, M., 1999. Exploitation of tropical oil seed plant Jatropha curcas L. Bioresour. Technol. 67, 73-82.

Igbinosa, O.O., Igbinosa, E.O., Aiyegoro, O.A., 2009. Antimicrobial activity and phytochemical screening of stem bark extracts from Jatropha curcas (Linn). Afr. J. Pharm. Pharmacol. 3(2), 58-62.

Ingle, K.P., Deshmukh, A.G., Padole, D.A., Dudhare, M.S., Moharil, M.P., Khelurkar, V.C., 2017. Screening of insecticidal activity of Jatropha curcas (L.) against diamond back moth and Helicoverpa armigera. J. Entomol. Zool. Stud. 5(1), 44-50.

Jain, S., Sharma, M.P., 2010. Prospects of biodiesel from Jatropha in India: A review. Renew. Sustain. Energ. Rev. 14, 763-771.

Juliet, S., Ravindran, R.,Ramankutty, S.A., Gopalan, A.K.K., Nair, S.N., Kavillimakkil, A.K., Bandyopadhyay, A., Rawat, A.K.S., Ghosh, S., 2012. Jatropha curcas (Linn.) leaf extract-A possible alternative for population control of Rhipicephalus (Boophilus) annulatus. Asian Pac. J. Trop. Dis. 2, 225-229.

Kalimuthu, K., Vijayakumar, S., Senthilkumar, R., 2010. Antimicrobial activity of the biodiesel plant, Jatropha curcas L. Int. J. Pharma BioSci. 1(3), 1-5.

Kovendan, K., Murugan, K., Vincent, S., Kamalakannan, S., 2011. Larvicidal efficacy of Jatropha curcas and bacterial insecticide, Bacillus thuringiensis, against lymphatic filarial vector, Culex quinquefasciatus Say (Diptera: Culicidae). Parasitol. Res. 109(5), 1251-1257.

Kumar, A., Sharma, S., 2008. An evaluation of multipurpose oil seed crop for industrial uses (Jatropha curcas L.): A review. Industr. Crop Prod. 28, 1-10.

Kuta, F.A., Saidu, A.N., Aluwo, H.H., 2015. Antibacterial activity of the stem bark of Jatropha curcas L. against four bacterial species. Braz. J. Biol. Sci. 2(3), 75-78.

Lateef, F.A., Daudu, S.O., Jere, P., Yusuf, D., 2014. Insecticidal Effect of Jatropha curcas oil phorbol esters on the nymph, adult cockroaches and termites. Int. J. Appl. Sci. Engg. Res. 3(2), 495-503.

Makkar, H. P. S., Aderibigbe, A.O., Becker, K., 1998. Comparative evaluation of nontoxic and toxic varieties of Jatropha curcas for chemical composition, digestibility, protein degradability and toxic factors. Food Chem. 62, 207-215.

Makkar, H. P. S., Goel, G., Francis, G., Becker, K., 2007. Phorbol esters: Structure, biological activity and toxicity in animals. Int. J. Toxicol. 26, 279-288.

Mittelbach, M., Pernkopf, J., Junek, H., 1983. Diesel fuel derived from vegetable oils: preparation and use of rape oil methyl ester. Energ. Agric. 2, 369-384.

Narayani, M., Johnson, M., Sivaraman, A., Janakiraman, N., 2012. Phytochemical and antibacterial studies on Jatropha curcas L. J. Chem. Pharmaceut. Res. 4(5), 2639-2642.

Ojiako, F.O., Dialoke, S.A., Ihejirika, G.O., Ahuchaogu, C.E., Iheaturueme, H.I., 2014. Management of stored maize against Sitophilus zeamais Motschulsky (Coleoptera: Curculionidae) with the seed and root powders of Jatropha curcas (L.). Int. J. Agric. Rural Devel. 17(3), 1899-1904. 
Ojiako, F.O., Ihejirika, G.O., Aguwa, U.O., 2015. Comparative bioactivity of different solvent extracts of the root and seeds of Jatropha curcas L. and chlorpyrifos against tailor ants (Oecophylla longinoda Latreille) (Hymenoptera: Formicidae). FUTO J. Series. 1(2), 118-211.

Olapeju, O., Aiyelaagbe, O. O., James, B., Gloer, J.B., 2008. Japodic acid, A novel aliphatic acid from Jatropha podagrica Hook. Rec. Nat. Prod. 2(4), 100-106.

Openshaw, K., 2000. A review of Jatropha curcas: An oil plant of unfulfilled promise. Biomass Bioener. 19, 1-15.

Rachana, S., Agarwal, T., Rastogi, R., Arora, N. Rastogi, M., 2012. Comparative analysis of antibacterial activity of Jatropha curcas fruit parts. J. Pharmaceut. Biomed. Sci. 15(12), 1-4.

Rampadarath, S., Puchooa, D., Jeewon, R., 2016. Jatropha curcas L: Phytochemical, antimicrobial and larvicidal properties. Asian Pac. J. Trop. Biomed. 6(10), 858-865.

Ratnadass, A., Wink, M., 2012. The phorbol ester fraction from Jatropha curcas seed oil: Potential and limits for crop protection against insect pests. Int. J. Mol. Sci. 13, 16157-16171.

Sarin, R., Sharma, M., Sinharay, S., Malhotra, R.K., 2007. Jatropha-Palm biodiesel blends: An optimum mix for Asia. Fuel. 86, 1365-1371.

Sauerwein, M., Sporer, F., Wink, M., 1993. Insecttoxicity of phorbol esters from Jatropha curcas seed oil. PlantaMed. 59, A686-A686.

Setha, B., Laga, A., Mahendradatta, M., Firdaus., 2014. Antibacterial activity of leaves extracts of Jatropha curcas Linn. against Enterobacter aerogenes. Int. J. Scient. Technol. Res. 3(1), 129-131.

Sharma, A. K., Gangwar, M., Tilak, R., Nath, G., Sinha, A.S.K., Tripathi, Y.B., Kumar, D., 2012. Comparative in-vitro antimicrobial and phytochemical evaluation of methanolic extract of root, stem and leaf of Jatropha curcas Linn. J. Pharmacol. Pharmacotherap. 4, 34-40.

Shelke, S.S., Jadhav, L.D., Salunkhe, G.N., 1987.
Ovicidal action of some vegetable oils and extracts on the storage pest of potato, Phthorimaea operculella Zell. Biovigyanam. 13, 40-44.

Stirpe, F.A., Pession-Brizzi, E., Lorenzoni, P., Sperti, S., 1976. Studies on the protein from seeds of Croton tiglium and of Jatropha curcas: Toxic properties and inhibition of protein synthesis in vitro. Biochem. J. 156, 1-6.

Suhaili, Z., Yeo, C.C., Yasin, H.N., Badaludin, N.A., Zakaria, Z.A., 2011. Antibacterial profile of Jatropha curcas latex extracts against selected human pathogenic bacteria. Afr. J. Microbiol. Res. 5(29), 5147-5154.

Takeda, Y., 1982. Development Study on Jatropha curcas (Sabu Dum) Oil as a Substitute for Diesel Engine Oil in Thailand. Interim Report of the Ministry of Agriculture, Thailand.

Tamalampudi, S., Talukder, M. R., Hama, S., Numata, T., Kondo, A., Fukuda, H., 2007. Enzymatic production of biodiesel from Jatropha oil: A comparative study of immobilized-whole cell and commercial lipases as a biocatalyst. Biochem. Engg. J. 39(1), 185-189.

Tiwari, K.A., Kumar, A., Raheman, H., 2007. Biodiesel production from Jatropha oil (Jatropha curcas) with high free fatty acids: an optimized process. Biomass Bioener. 31, 569-575.

Verma, M., Pradhan, S., Sharma, S., Naik, S. N., Prasad, R., 2011. Efficacy of karanjin and phorbol ester fraction against termites (Odontotermes obesus). Int. Biodeter. Biodegrad. 65, 877-882.

Weike, C., Qi, Z., Xingchun, C., Kexiu, W., Ying, X., Lin, T., Shenghua, W., Jie, B. A., Fang, C., 2006. Chemical modification of Jatropha curcas RIPs (curcin) and effect of the modification on relative activity of curcin. Chin. J. Appl. Environ. Biol. 12, 329-333.

Zewdneh, T., Mamuye, H., Asegid, T., Yalemtsehay, M., Beyene, P., 2011. Larvicidal effects of Jatropha curcas L. against Anopheles arabiensis (Diptera: Culicidae). Momona Ethiop. J. Sci. 3, 52-64.

How to cite this article:

Sharma, N., 2017. Evaluation of Jatropha curcas as potential biocide and biopesticide. Int. J. Curr. Res. Biosci. Plant Biol. 4(6), 92-97. doi: https://doi.org/10.20546/ijcrbp.2017.406.011 